УДК 37.017.4 + 745+ 373.3.016:742

\author{
Наталя Степанюк, \\ ORCID iD 0000-0002-5677-2734 \\ старший викладач \\ кафедри теорії й методики мовно-літературної \\ та художньо-естетичної освіти \\ Миколаӥвський обласний інститут \\ післядипломної педагогічної освіти \\ вул. Адміральська, 4-а, 54001, м. Миколаїв, Україна \\ natalia.stepaniuk@moippo.mk.ua
}

\title{
ТАВРІЙСЬКІ ВІЗЕРУНКИ
}

Статтю присвячено таврійському розпису - унікальному декоративному мистецтву Миколаӥвського краю, історї його виникнення $і$ особливостям символіки й орнаментики, кольорової гами та специфіки нанесення елементів зображення. Розкрито методику опанування таврійського розпису на шкільних уроках образотворчого мистецтва та в умовах гуртка, методи й прийоми навчання учнів початкової школи, які конкретизовані на прикладах виконання ними окремих елементів таврійського розпису й цілісної композичіï. Наведено покроковий супровід використання учнями 1 і 2 класів композицій на основі таврійського розпису, який вивчається в рамках тем програми курсу «Мистецтво» в загальноосвітній школі.

Ключові слова: гурток декоративно-прикладного мистецтва; таврійський розпис; уроки образотворчого мистецтвв; учні початкової школи.

(C) Степанюк Н. К., 2021

Вступ. Для розвитку будь-якого суспільства важливим є усвідомлення громадянами свого коріння, історії, культури і традицій. Роль української культури та їі вивчення молодим поколінням особливо актуалізувалися в наш час, коли Україна виборює своє право на незалежність та самоідентифікацію.

Особливе значення в українському мистецтві й культурі мають мистецькі осередки, пов'язані $з$ народними традиціями малювання: петриківський, самчиківський, таврійський розписи. Найбільш дослідженим $є$ петриківський розпис. Його стилістику, історію виникнення та розвитку вивчали Л. Левитська, Є. Берченко, Б. Бутнік-Сіверський, Н. Глухенька, О. Найден, Ю. Смолій та ін. Дослідники збирали зразки петриківського розпису ще на початку 1900-х років (Д. Яворницький, Є. Евенбах). Відомими на весь світ стали майстри цього живопису Ф. Панко, В. Соколенко, А. Пікуш, Т. Пата, Н. Білокінь, О. Пилипенко, Г. Ісаєва, Н. Тимошенко та ін. Сучасні педагоги (О. Харченко, Н. Горшкова-Кандаурова та ін.) пропонують учителям i керівникам художніх студій методичні напрацювання 3 досліджень особливостей композиції, прийомів і засобів, художньо-технічного забезпечення в петриківському декоративному малюванні.

Вивчення самчиківського розпису (самчиківки) - одного з найдавніших видів народного декоративного мистецтва здійснюється на основі польових записів. Інформацію можна отримати 3 теоретичних досліджень М. Селіванової «Лексикон української орнаментики», М. Кириченко «Український народний декоративний розпис», Р. Захарчук-Чугай, Є. Антоновича «Українське народне декоративне мистецтво», Б. Рибакова «Язычество древних 
славян», Л. Самаріної «Традиционная этническая культура и цвет». Малодослідженим залишається побутування самчиківки

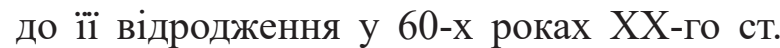
Найвідоміші майстри: О. Пажимський, М. Юзвур, В. Раковський, С. Касьянов.

Менш знаним серед широкого кола молодих науковців, учителів $є$ таврійський розпис. Його дослідження започаткувала Свгенія Бондаренко (1928-2014), журналістка, письменниця, художниця. Вона першою привернула увагу до розвитку в $50-x$ роках XX ст. «За нескінченну любов до рідного краю її назвали «Пресвітлою лебіддю Миколаївщини» (Паранюк Л., 2019, с. 2).

Сьогодні над збереженням традицій таврійського розпису та його популяризацією плідно працюють методисти Миколаївського обласного центру народної творчості та культурно-освітньої роботи: здійснюють етнографічні експедиції та поїздки за програмою культурної акції «Від громади до громади», реалізують навчально-методичний проєкт «Обереги рідної землі». У рамках цих проєктів науковці й методисти центру збирають унікальний етнографічний матеріал щодо особливостей оздоблення житла та характерних елементів декору, притаманних нашому краю; записують пісні й легенди, описують обряди та традиції міст і сіл Причорномор'я.

Таврійський живопис $є$ культурною нематеріальною спадщиною півдня Миколаївщини й потребує грунтовного дослідження, методичних розробок для вчителя 3 метою його вивчення, популяризації серед учнів загальноосвітніх і художніх шкіл; він має значний художньо-педагогічний потенціал у загальнокультурному розвитку учнів та їхньому мистецькому навчанні, що доведено власною педагогічною практикою. Тож мета статті полягає в розкритті особливостей таврійського розпису, презентації ефективних методів і прийомів навчання учнів початкової школи на уроках образотворчого мистецтва i в гуртках (на прикладі гуртка «Веселкова палітра»).

Реалізація поставленої мети передбачала виконання таких завдань:
- розглянути таврійський розпис i його специфіку;

- виявити особливості розвитку графічних умінь молодших школярів у процесі навчання цього декоративного розпису;

- описати методику опанування таврійського розпису на уроках образотворчого мистецтва в початковій школі;

- розкрити умови, що сприяють успішному опануванню молодшими школярами таврійського розпису як засобу художнього і загальнокультурного розвитку учнів.

Виклад основного матеріалу. Надважливим завданням сім'ї і школи $є$ формування свідомого громадянина, патріота України. Серед основних пріоритетів освіти - виховання шанобливого ставлення до своєї культури, історії, традицій і звичаїв, державної мови, національних цінностей українського народу та інших народів і націй. Уроки образотворчого мистецтва відіграють важливу роль у розвитку культурної, творчої особистості, їі художньо-естетичному вихованні. Учитель заохочує учнів до сприймання й аналізу зразків декоративно-ужиткового мистецтва, що найкраще відображають самобутність українського народу, допомагають відновлювати історично-духовну пам'ять і зосереджують увагу учнів на глибинах естетичної та педагогічної свідомості всього українського етносу. Вивчення мистецтва із залученням кращих зразків із рідного краю - найефективніший спосіб надихнути дітей, оскільки учні із більшою зацікавленістю сприймають близьку з дитинства культурну спадщину.

Народні промисли на території України пов'язані з різними видами декоративно-ужиткового мистецтва: керамікою с. Опішня (Полтавська обл.), с. Косово (Івано-Франківщина); килимарством c. Решетилівка (Полтавська обл.), с. Косово (Івано-Франківщина); художньою вишивкою - с. Клембівка (Вінницька обл.), с. Решетилівка (Полтавська обл.); розписом 
- с. Петриківка (Дніпропетровська обл.); різьбленням по дереву - с. Вижниця (Чернівецька обл.); розписом меблів та іграшок - с. Яворів (Львівська обл.) та інші. Кожен iз промислів є своєрідним і унікальним, має власну історію та етапи становлення, своїх майстрів, які передають із покоління в покоління збережені впродовж століть первинні мотиви, колорит, прийоми, особливості технологічного процесу. Оволодіти таким мистецтвом - справа складна й довготривала, тому починати варто змалечку. Зокрема загальноприйнятими прийомами пензлевого розпису можуть оволодіти навіть діти молодшого шкільного віку під умілим керівництвом учителя.

Таврійський розпис є найяскравішою візитівкою Миколаївщини. С. П. Бондаренко, подорожуючи в 1950-х рр. Причорномор'ям, зацікавилася роботами мазальниць (так називали жінок, які розписували хати). Свої враження вона відобразила у власних малюнках, у численних публікаціях, у збірці новел «Стежки до Лиману». Саме у статті «Степові скарби» С. П. Бондаренко називає унікальний розпис півдня Миколаївщини таврійським, а про сюжетні композиції з життя степовиків пише: «Поєднання в одному творі натурального пейзажу і фантастичного казкового сюжету з елементами народного розпису аж ніяк не руйнує класичної народної традиції, а $є$ сучасним їі розвитком» (Бондаренко Є. П., 2004, с. 48).

Таврійський розпис $\epsilon$ унікальною системою декоративно-орнаментального оздоблення. У візерунках та орнаменті переважає морська, рослинна та тваринна тематика. Порівняно 3 петриківським та самчиківським розписами, яким притаманні побутові сюжети, рослинна (квіткова) та пташина тематика, таврійський розпис відображає життя, пов'язане $з$ морем, риболовством. Навіть основні елементи таврійського розпису мають характерні назви: «риба», «матула», «маяк», «медуза», «якірці», «парусник», «морський коник», «краб», «Роза вітрів» і основні мазки: «хвиля», «човник», «хмарка», «краплинка», «чайка», «човник із вітрилом» (Бондаренко Є. П., 2004, с. 48).
Усі ці морські, рослинні та тваринні образи ще 3 прадавніх часів виконували функцію оберегів: наші пращури вірили, що вони зможуть захистити від нещасть. Перші символи-обереги використовували в оздобленнях вишиванок та осель. Так, наприклад, над дверима хат, обабіч вікон зображували пару білих лебедів, які повинні закрити крилами оселю та родину від лиха. У декоруванні осель використовували рапортний орнамент (повторення мотиву).

Окрім рослинних і тваринних образів, у таврійському розписі $є$ й самобутні - притаманні саме йому. Так, Є. П. Бондаренко зазначає: «...на хатніх стінах, повернутих до берега, ще в сімдесятих роках $\mathrm{XX}$ ст. можна було побачити видовжену постать жінки з червоною квіткою в піднятих руках» (Бондаренко Є. П., 2004, с. 48) - це символ маяка, який освічує рибалкам дорогу додому, - він став основною графемою Берегині Таврійського краю. Ї̈̈ називають «постать Праматері-Берегині», «Берегині зі світлом», «Берегинею-Маяківною». Часто у вигляді Берегині зображували мазальницю.

Самобутнім елементом таврійського розпису є образ матули (матула - таврійська рибальська сіть, що символізує тісний зв'язок між природою і людиною. Матула стає в народній уяві Долею, яка пов'язує кількох людей у сім'ю, рибалку з морем, матір із дитиною, хату 3 хвилями, землю 3 водою (Бондаренко Є. П., 2004, с. 48).

Ще одним характерним елементом в орнаменті $\epsilon$ вітрила - їх зображають у вигляді жіночих хусток, пташиних крил, козацьких шароварів, пелюсток квітів, рушників, спідниць. «Білі вітрила - символ сили морської стихії, могутності морських вітрів» (Паранюк Л., Божкова Г., 2019, c. 14).

Виконання таврійського розпису має свої особливості. Фон у ньому білий чи блідо-блакитний, на якому зображують білі та сині хмарки, зірочки й краплинки, зернятка та квіти. Із птахів найчастіше малюють блакитних журавлів, які є провісниками дощу, і ластівок, яких можемо спостерігати на морському узбережжі. Роз- 
пис завжди відображає побут народу. А оскільки Миколаївщина здавна славиться рибальством, то в сюжетах часто $є$ зображення риби, рибальської сітки, човна (про що йшлося вище), малювали також самих рибалок. Серед образів людей - «Мазальниці», «Жінки-акації» (у О. Бондаренко - «Матінка акація»), а ще - дідусь і бабуся (як наприклад, у настінному розписі Є. П. Бондаренко «Доля»); жіноча постать у композиції «Човен».

Таврійський розпис за технікою виконання $€$ пензликовим, але можливе використання й техніки заливки кольором окремого фрагмента (заливка - заповнення фону або окремої частини зображення одним кольором) - у такий спосіб зображували предмети побуту чи постаті людей. Однак поверх заливки обов'язково промальовували пензликом окремі елементи - обличчя, волосся, складки чи орнаменти на одязі за принципом вишивки.

«Історично кольорова гама таврій- ського розпису формувалася відповідно до наявності доступних природних барвників: вапна і крейди, сажі й вахри, різних видів глини (жовтої, білої, рудої, червоної), а також барвників рослинного походження, які виготовлені з трав, листя, квітів, соку ягід. Для стійкості фарби додавали жовток і молоко» (Паранюк Л., Божкова Г., 2019, c. 14). Використовували такі кольори: білий, колір «сивого туману», багато відтінків блакитного і синього аж до чорного (ластівки, човники, якірці), рідше - рожевий, бузковий, зелений (Бондаренко Є. П., 2004 , с. 49). В основу композиції клали прості елементи, які наносилися на вертикальну площину невеличкими віхтиками густою фарбою, замішаною на вапні: «човник» (фото 1), «хвилька» (фото 2), «гачок» (фото 3), «краплинки», «лінії», «рисочки» (фото 4), «руки берегині» (фото 5), «роза вітрів» (фото 6) (Паранюк Л., 2019, Божкова Г., с. 5).
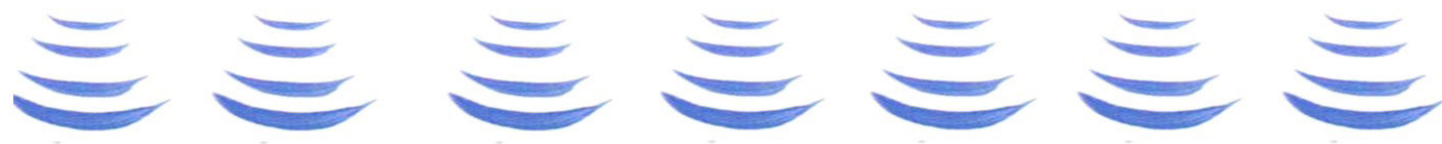

Фото 1. Елемент «Човник»

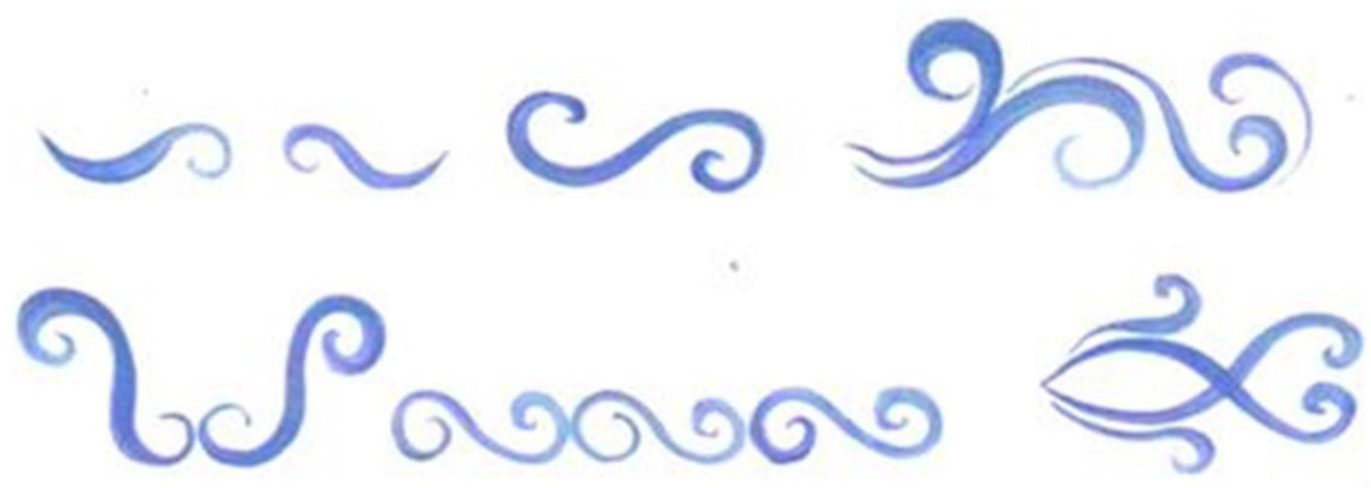

Фото 2. Елемент «Хвилька»
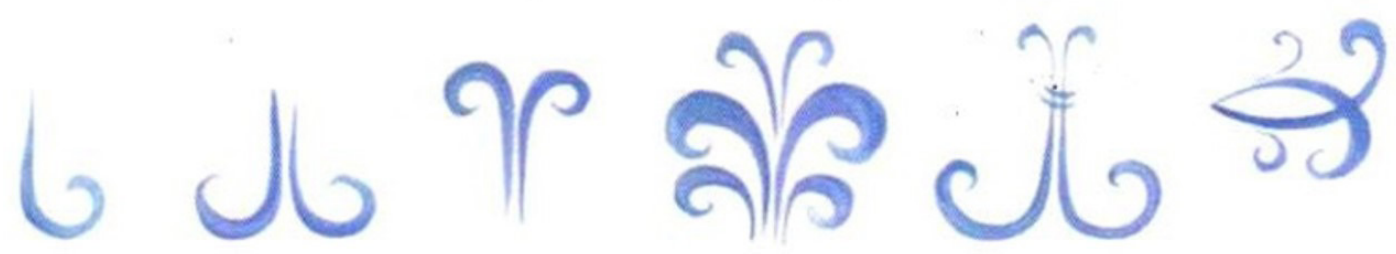

Фото 3. Елемент «Гачок» 

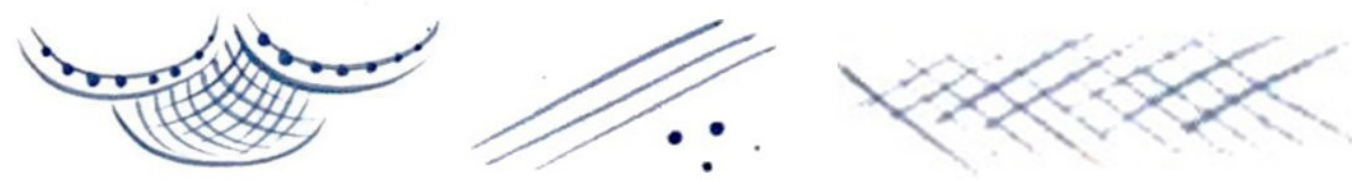

Фото 4. Елементи «Рисочки»
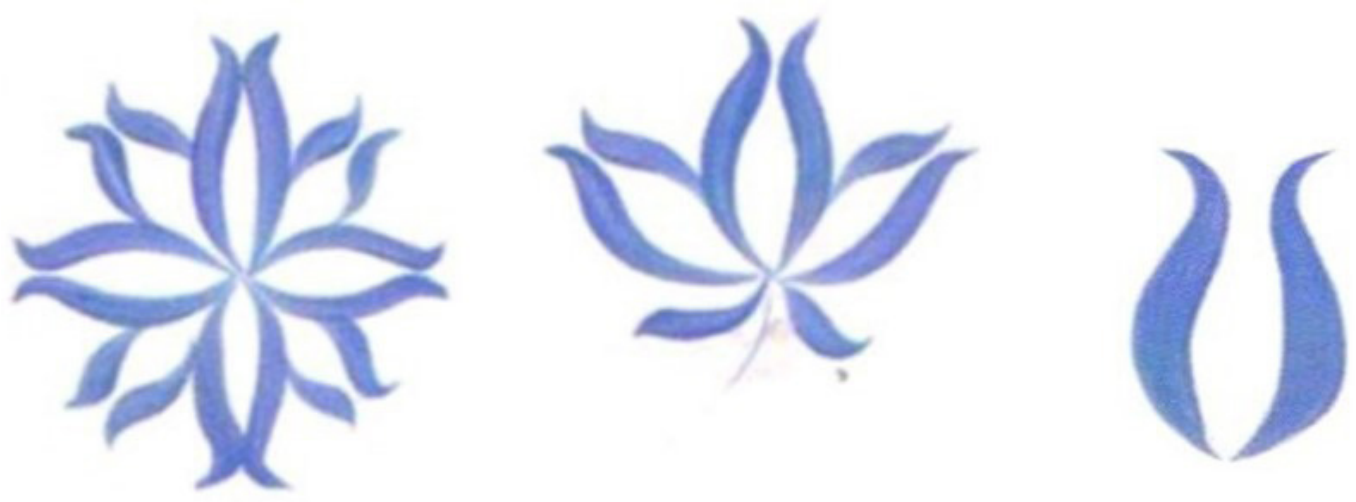

Фото 5. Елемент «Руки Берегині»

Кожен з елементів відрізняється технікою виконання. В основу «хвильки» та «човника» покладений горизонтальний мазок, однак у першому елементі він має продовження у вигляді завитка (може бути 3 обох боків мазка), а другий починається 3 тонкого мазка, потім кладеться широкий і закінчується знову тонким мазком. Елемент «гачок» починається як «краплинка», але має продовження у вигляді завитка (може бути 3 обох боків). Елемент «руки Берегині» виконується вертикально, схожий на елемент «човник», однак верхній кінчик вигинається в протилежний бік від нижнього. «Крапки», «рисочки», «лінії» вважаються другорядними елементами, оскільки не виконують основної функції в розписі, але вдало доповнюють композицію. Візитівкою розпису є елемент «Роза вітрів» - образ жінки-берегині з рятівним вогнем у піднесених вгору руках, що $\epsilon$ втіленням маяка. Центром будь-якої композиції, створеної з елементів «руки Берегині», $є$ провідна зірка (Паранюк Л., Божкова Г.,2019, с. 7-14).

Однак не тільки елементи створюють унікальність таврійського розпису. Його композиційною особливістю $є$ ставлення до простору, прагнення передати його безмежність. Простір не перевантажений деталями декору, що дозволяє зосереди- ти увагу на сюжеті. Відчуття безмежності відтворено і в орнаменті, який прозоріший за ритмікою, позбавлений геометризму. Постаті людей, коней, птахів трохи видовжені порівняно з аналогічними образами в декорі інших регіонів. Колорит композиції визначається сонячними променями, пропущеними крізь туман над водою, що створює неповторну перламутрову гаму, багату світлими напівтонами природи. Схожі елементи використовували й у візерунках вишиванок (Бондаренко Є. П., 2004, с. 49).

Нині традиції таврійського розпису продовжують розвивати майстрині О. Бороздіна, А. Яковлева. А талановиту художницю, викладачку Куцурубської школи мистецтв (Куцурубської об'єднаної територіальної громади Очаківського р-ну Миколаївської обл.) Любов Паранюк називають берегинею таврійського розпису. Закохавшись іще в студентські роки в красу народного мистецтва, вона крок за кроком відтворює у своїх роботах чарівні образи, докладні описи яких залишила С. П. Бондаренко. Свої знання і вміння мисткиня передає учням - юним і вже досвідченим майстрам. Вона $\epsilon$ учасницею різноманітних обласних виставок майстрів творчого об’єднання «Прибужжя», обласних семінарів. 2019 року вийшла друком праця Л. Паранюк і Г. Божкової «Таврійський розпис». 
Спираючись на цей доробок, маємо можливість упроваджувати таврійський розпис у курсі «Мистецтво» в початковій школі. У власній педагогічній практиці використовуємо підручники О. Калініченко, Л. Арістової «Мистецтво» (для 1 і 2 класів) (2018-2019 рр.). Так, у першому класі, оз- найомлюючи учнів із поняттям «орнамент» (тема 4), розглядаємо різноманітні орнаменти, характерні для України; увагу також зосереджуємо на візерунках таврійського розпису, його складових елементах і найпростіших орнаментальних і кольорових сполученнях.

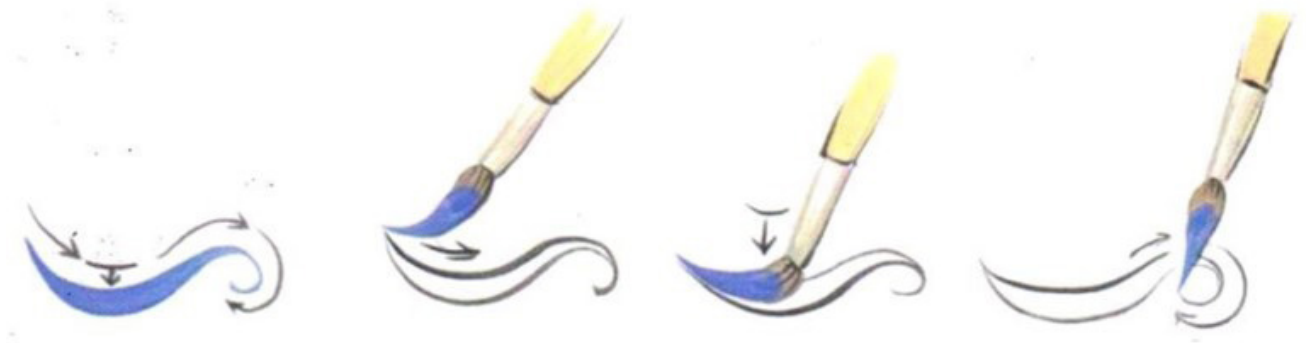

Техніка виконання елемента «Хвилька»

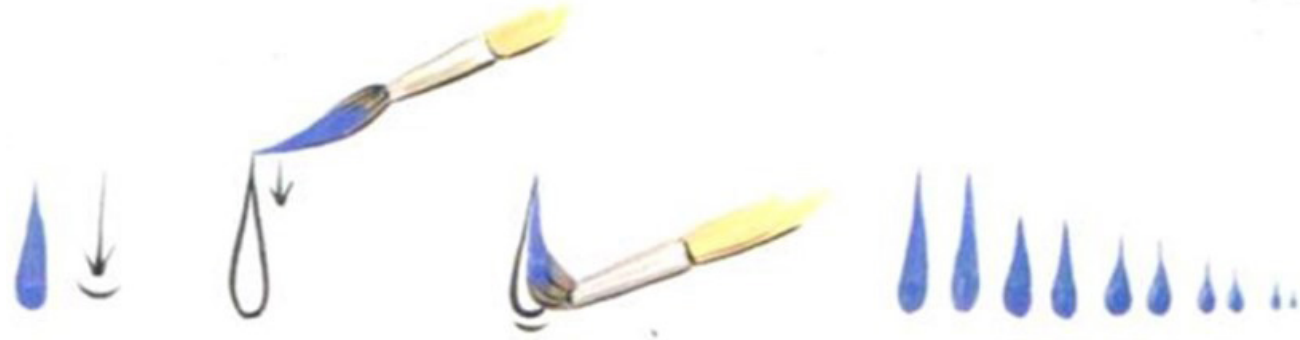

Техніка виконання елемента «Краплинка»

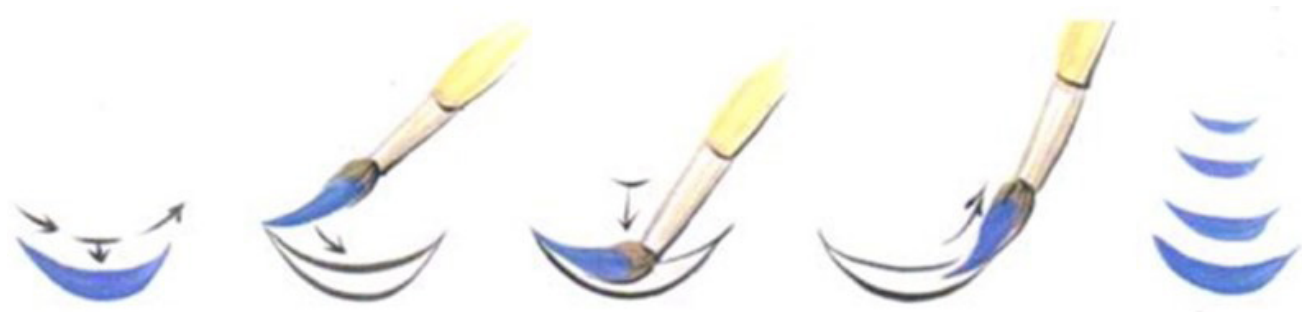

Техніка виконання елемента «Човник»

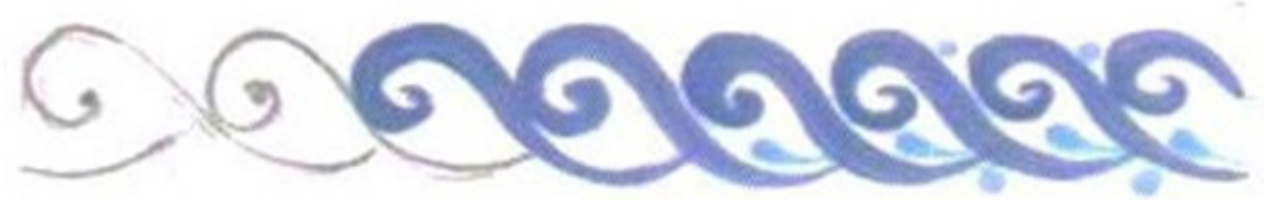

Фото 7. Техніки виконання елементів «Хвилька», «Краплинка», «Човник»
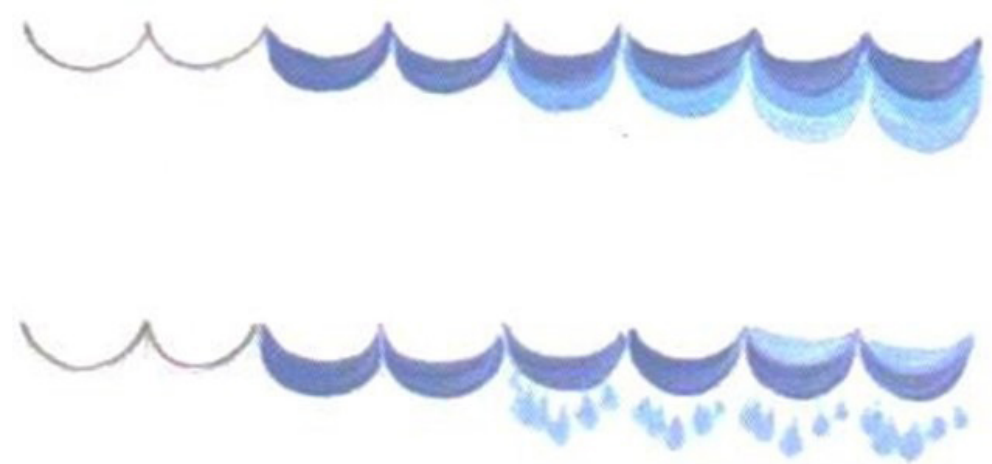

Фото 8. Послідовність виконання орнаменту «Бігунецьь» 
Творчою роботою учнів для виконання на уроці $є$ відпрацювання мазків: «човник», «хвилька», «краплинка» (фото 7) та утворення 3 них найпростішого орнаменту «бігунець» (фото 8) на аркуші з графічною сіткою, накресленою олівцем, (бігунець - найпростіша стрічкова композиція, що будується на повторенні одного або двох елементів) (Паранюк Л., Божкова Г., 2019, c. 7).

Надалі, прикрашаючи орнаментом «бігунець» паперовий шаблон новорічної іграшки-дзвоника (тема 11 за цим же підручником), учні ускладнюють візерунок «човником із вітрилами» або «лебідкою» (фото 9), які наносять поетапно (Паранюк Л., Божкова Г.,2019, с. 19).
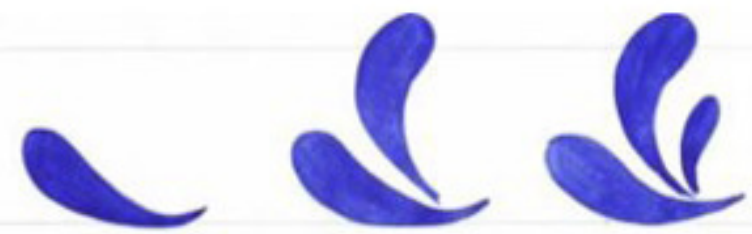

Послідовність виконання елемента «Човник із вітрилами»
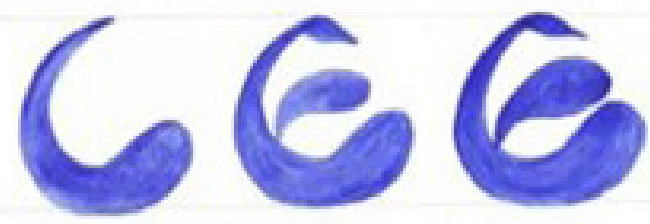

Послідовність виконання елемента «Лебідка»
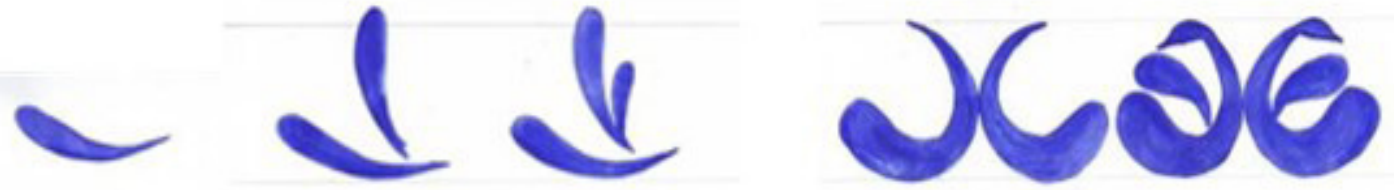

Фото 9. Елементи «Човник із вітрилами», «Лебідка»

Розглядаємо етапи виконання новорічної іграшки (фото 10):

I етап (фото 10-а). Учні малюють внизу іграшки орнамент з одного елемента

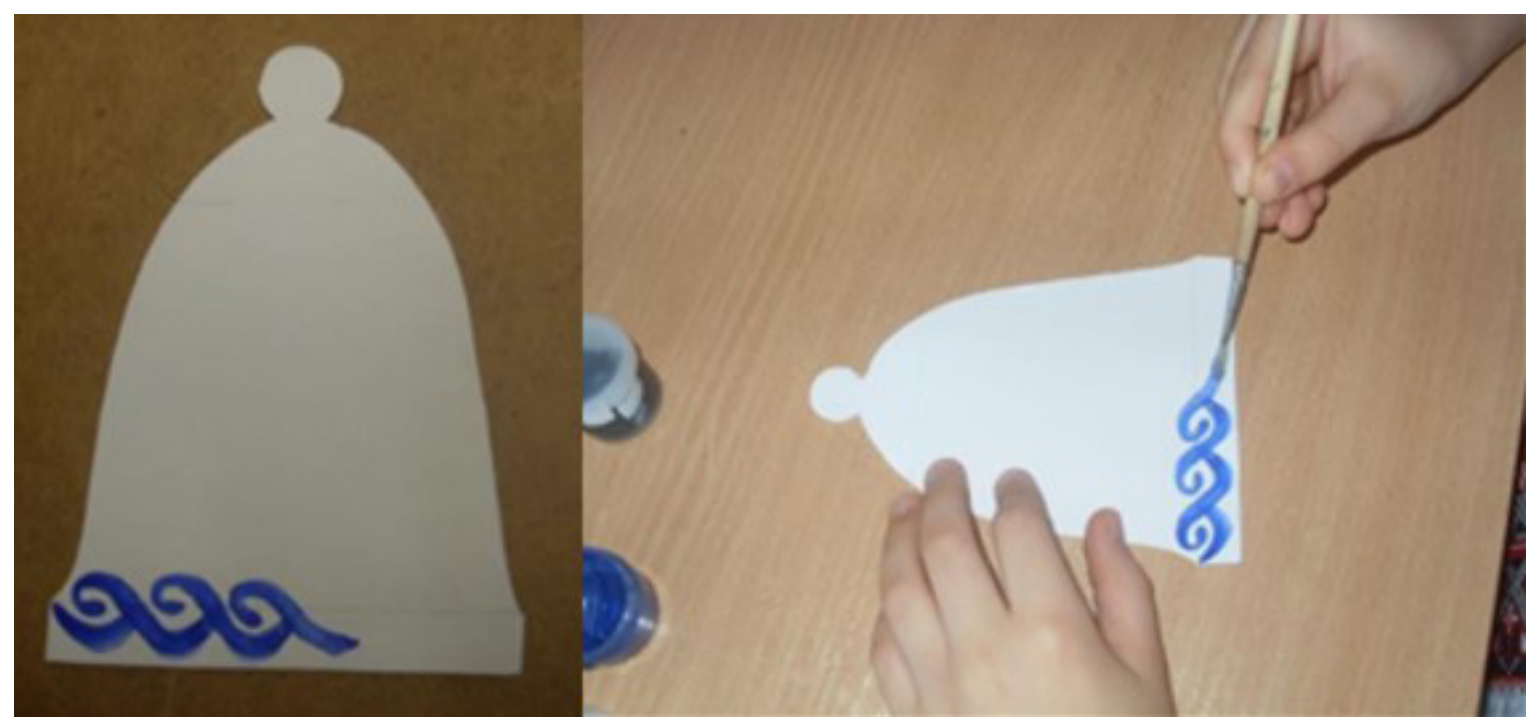

Фomo 10-a 
II етап (фото 10-б). Учні прикрашають край іграшки орнаментом з елементів «хвилька» $i$ «дощик»

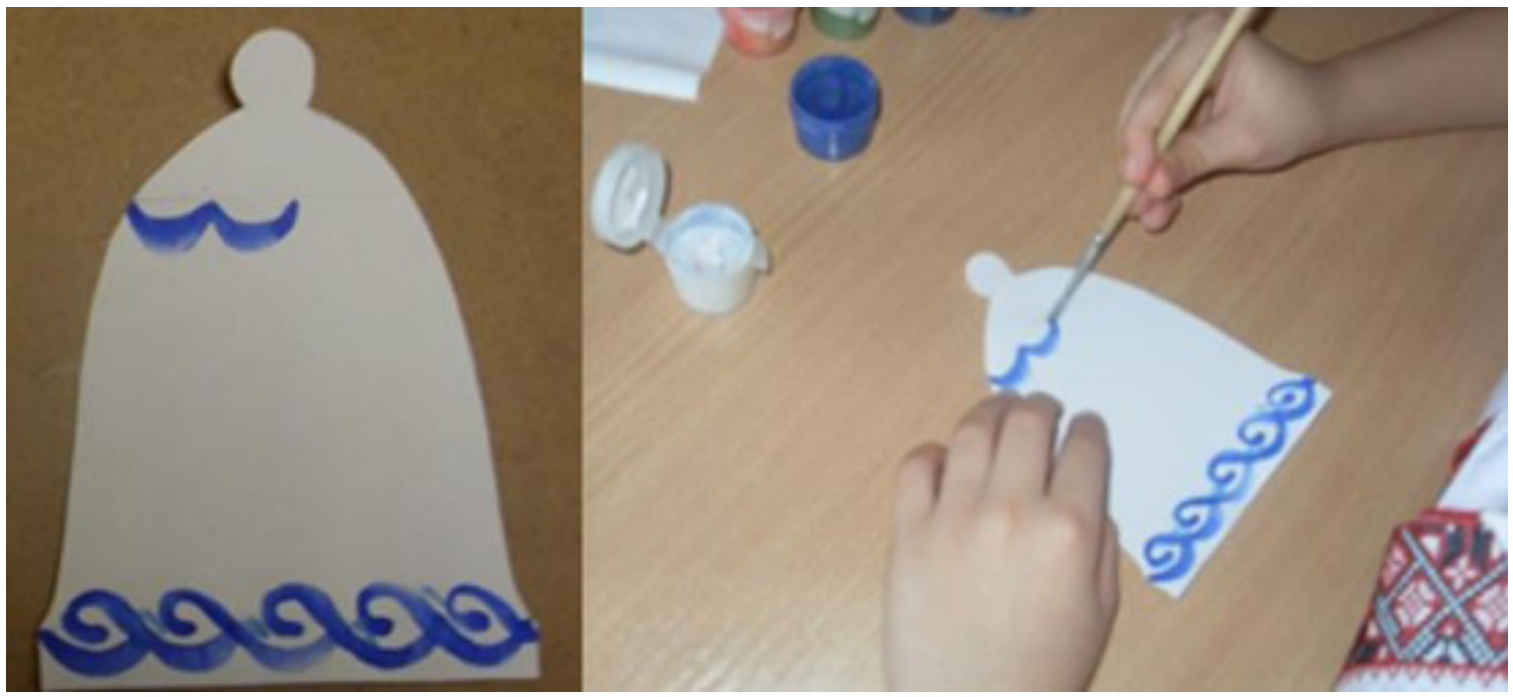

Фото 10-6

III етап (фото 10-в, 10-2). Малювання орнаменту "бігунець" на верхню частину іграшки-дзвоника і одного крупного елемента в центрі композиції

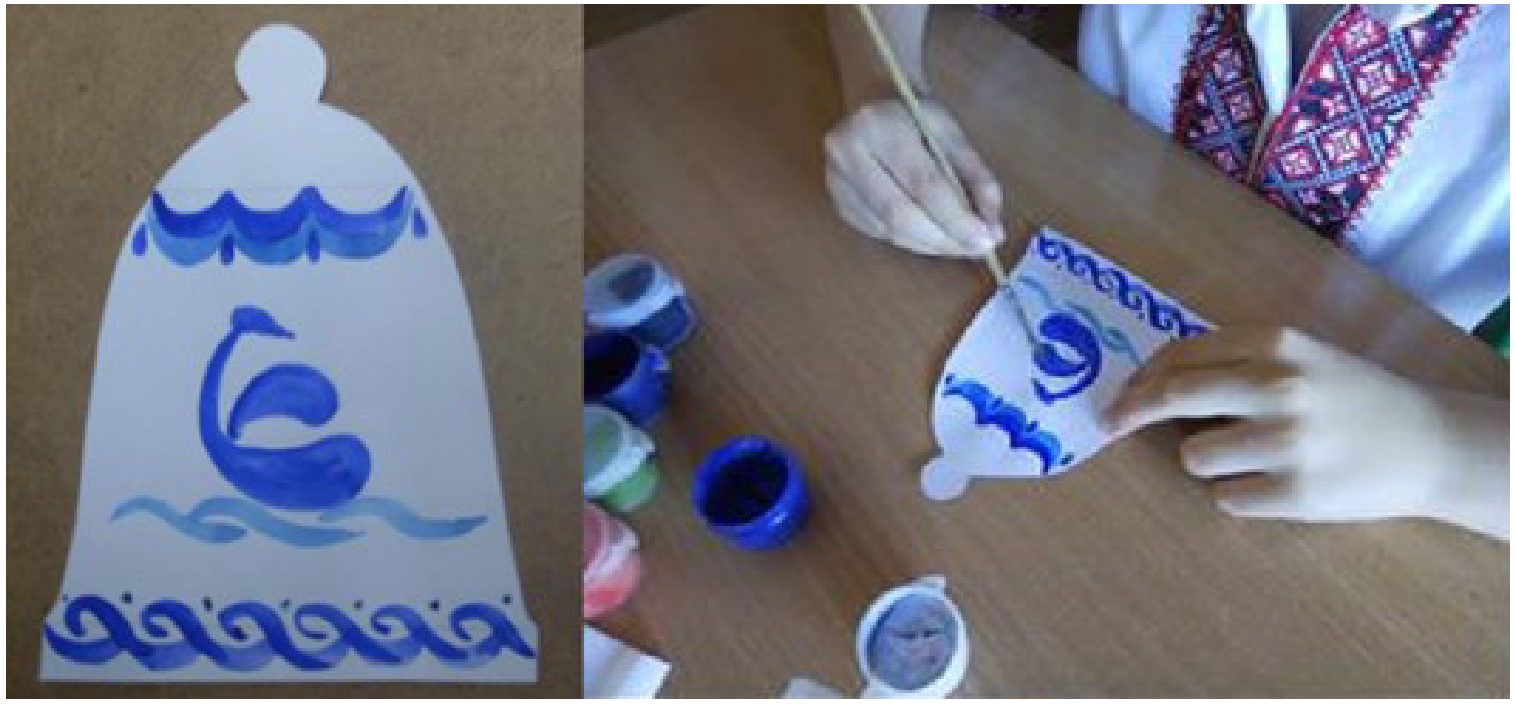

Фоmo 10-8

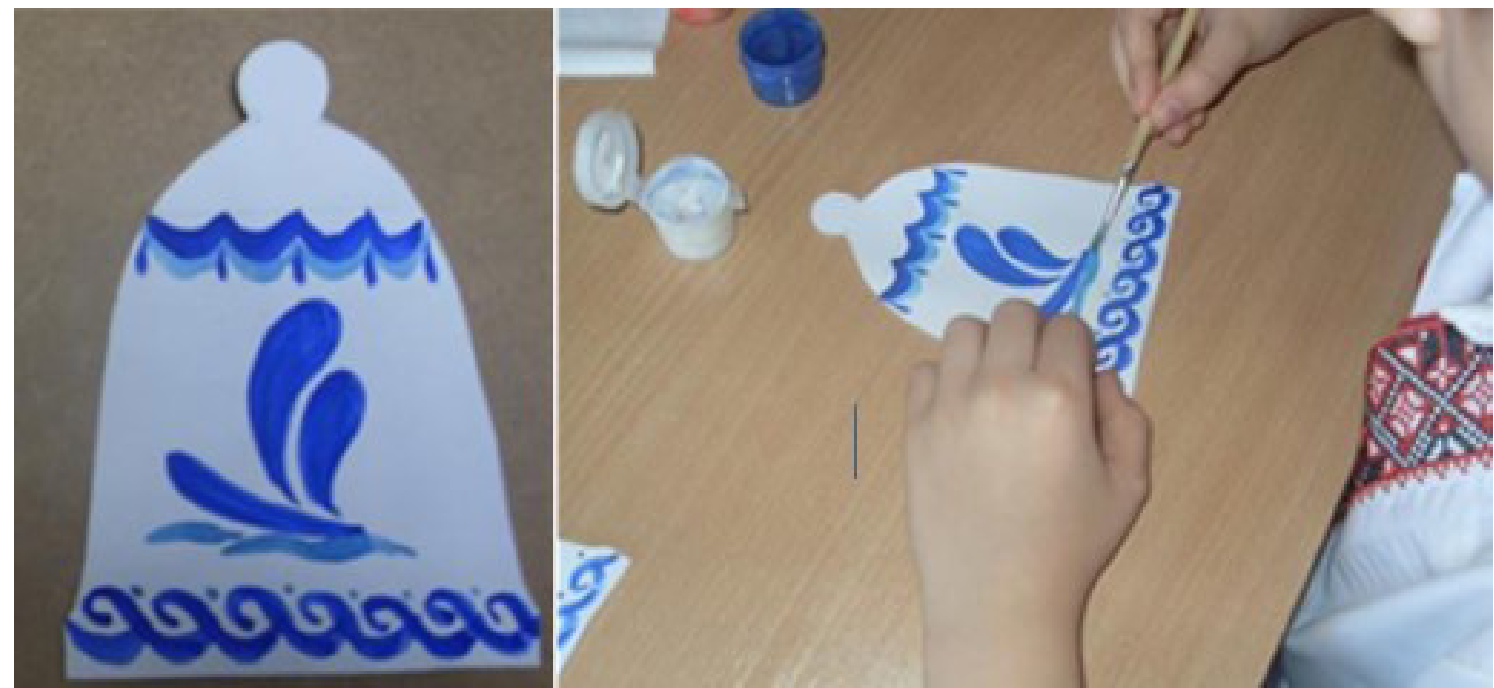

Фomo 10-2 


\section{IV етап (фото 10-д). Приклеювання кріплення до іграшки}

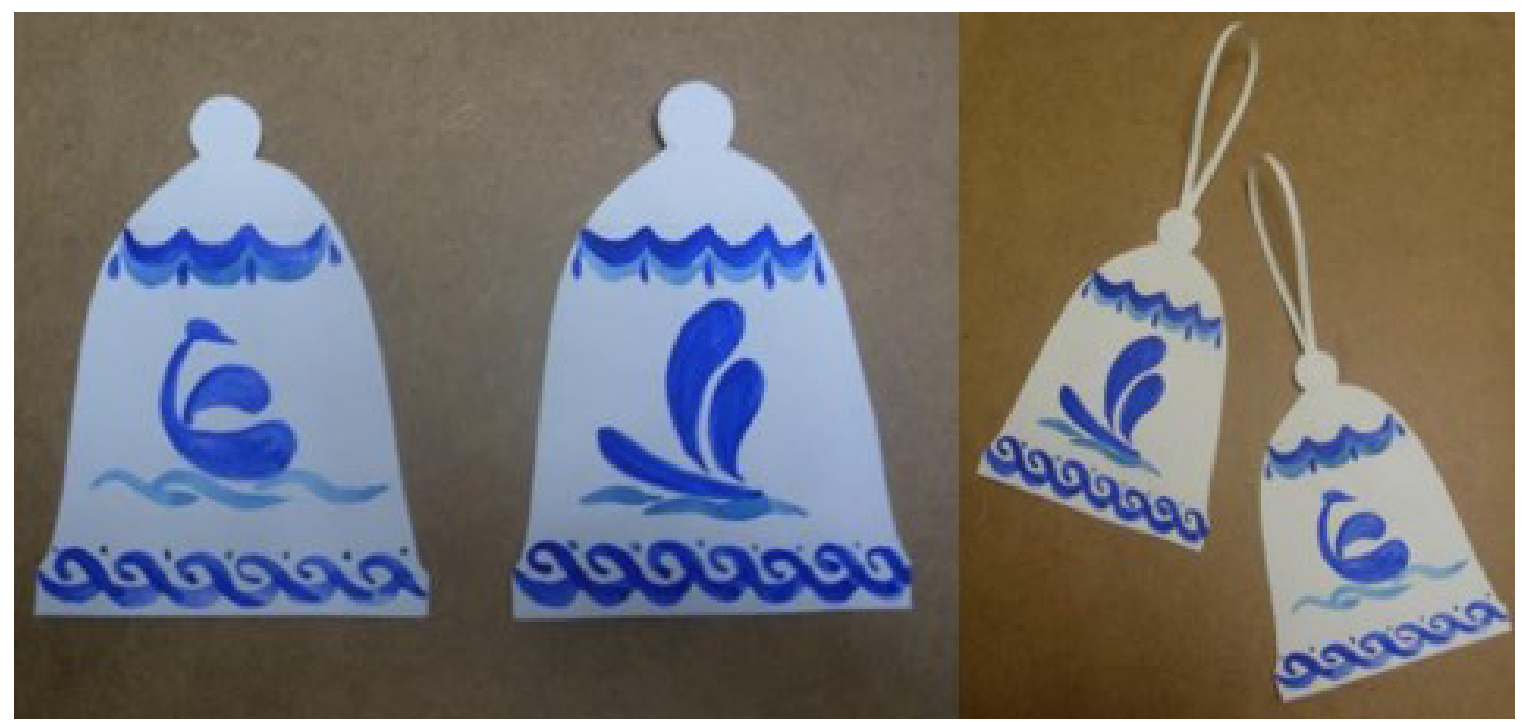

Фото 10- $\partial$

Такими іграшками прикрашаємо ялинку, класну кімнату.

У другому класі, ознайомлюючи учнів із поняттям «ритм» (тема 6, підручник «Мистецтво», 2 клас, автори О. Калініченко, Л. Арістова, 2019 ) і розглядаючи орнаменти українських рушників та розпису керамічних виробів, звернемо увагу молодших школярів на стрічковий орнамент таврійського розпису, спираючись на розпис керамічних виробів Л. Паранюк та іiі сюжетні композиції, оздоблені стрічковим орнаментом.

Виконуючи творчу роботу, повторюємо основні мазки таврійського розпису: «хвилька», «краплинка», «дощик», «човник», «хмарка» - та опановуємо прості зооморфні елементи: «рибка» або «лебідка». Вчимося компонувати ці елементи в стрічковий орнамент. Користуємося традиційними кольорами (відтінки синього та блакитного, вкраплюємо жовтий або жовтогарячий).

У третьому класі (тема 13 та 14, підручник «Образотворче мистецтво», 3 клас, автори О. Калініченко, В. Сергієнко, 2013) ознайомлюємося з красою народних виробів, докладніше зупиняємося на декоруванні керамічних виробів України. Порівнюємо розпис таврійський із косівським i опішнянським, петриківським. Звертаємо увагу на те, як будується композиція, розміщуються візерунки на глечиках або тарілках. У творчій роботі пробуємо відтворити вже створену композицію або з відомих елементів створюємо власну композицію (розпис шаблона тарілки таврійським розписом - зразки дитячих робіт див. на фото 12).

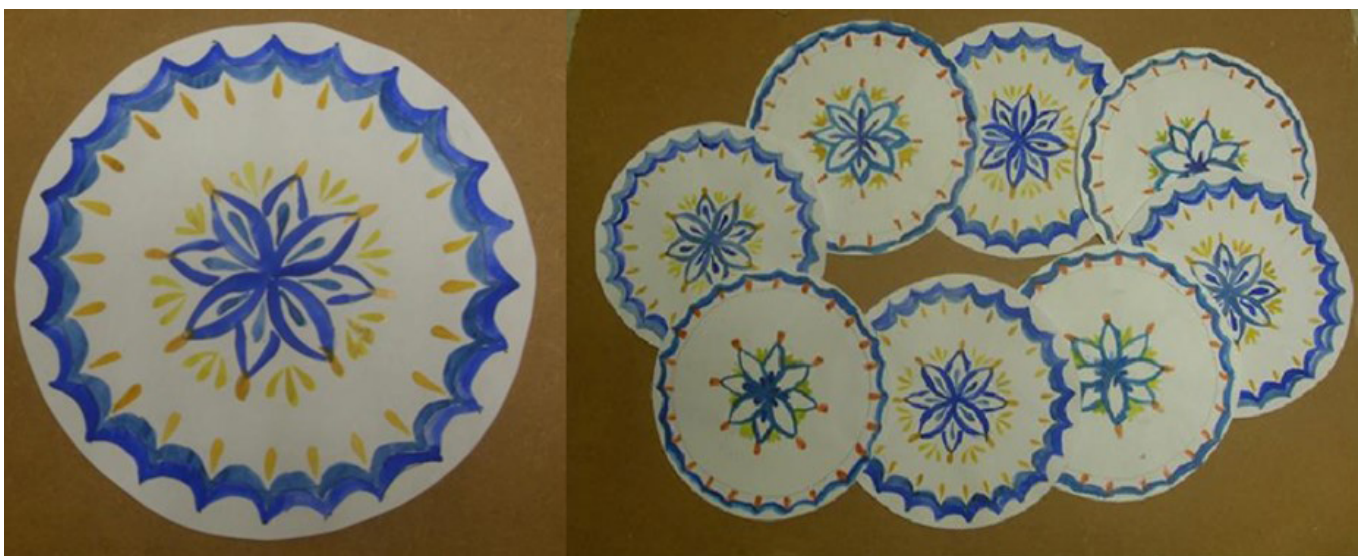

Фото 12. Розпис шаблона тарілки таврійським розписом (дитячі роботи) 
У четвертому класі, створюючи витинанку «Дерево життя» (тема 11, підручник «Образотворче мистецтво», 4 клас, автори О. Калініченко, В. Сергієнко, 2014), ознайомлюємося з темою на зразках, де відтворюється сюжет «Дерево життя» в різних видах декоративного мистецтва (вишиванка, розпис, ткацтво, різьблення по дереву тощо). Докладніше зупиняємося на тав- рійському розписі. Розглядаємо елементи, 3 яких складається дерево, і повторюємо кольорову гаму. Вибираючи колір паперу для витинанки, перевагу надаємо синім, блакитним кольорам (які притаманні таврійському розпису). I так на основі таврійського розпису створюємо витинанку «Дерево життя» (фото 13).

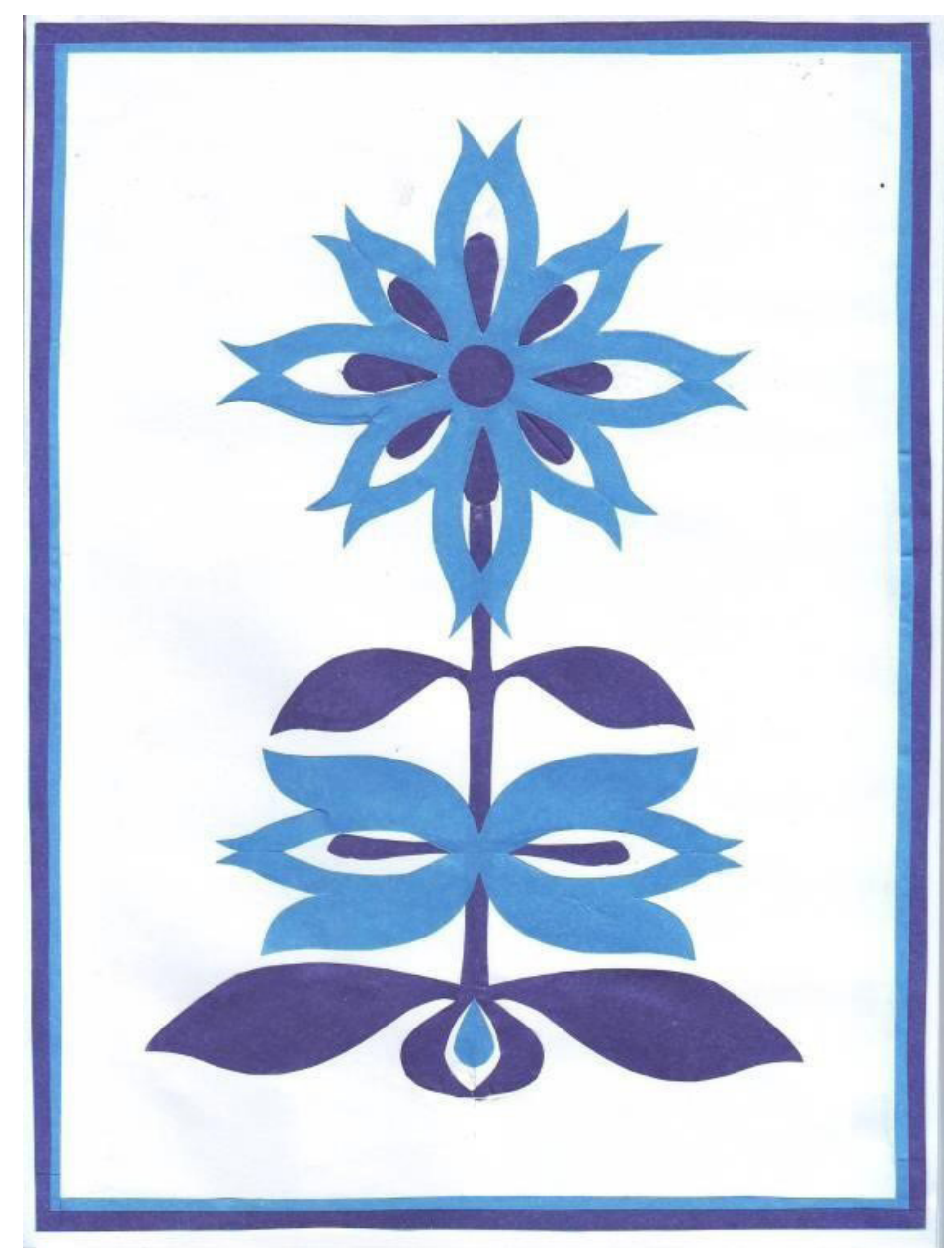

Фото 13. Дерево життя (дитяча робота)

Коли працюємо над темою «Декорування інтер'єру сільської хати» (тема 13, цей же підручник), нагадуємо, що спочатку таврійський розпис виник як техніка прикрашання хат Миколаївщини (ознайомлюємо учнів із роботами Є. П. Бондаренко «Сорока», «Кінбурнські коні» та ін.; О. Бондаренко «Матінка Акація», I. Черкесової «Мазальниця» (лялька-мотанка). Тут потрібно розповісти про «мазальницю», а потім обговорити з учнями сюжет цих творчих робіт, їхню колористику, візерунок.

На уроках перед проведенням прак- тичної роботи необхідно нагадати учням закономірності побудови орнаментальної композиції і супроводити розповідь наочним матеріалом: схемами, картками, прикладами, кресленнями. На заняттях гуртка 3 образотворчого мистецтва «Веселкова палітра» діти опановують складніші елементи розпису та намагаються створити власну декоративну композицію. Працюють над шаблонами глечиків (фото 14) та куманців (фото 15), тарелі із зооморфними елементами (фото 16) та рішенням розписної композиції «Дерево життя» (фото 17). 


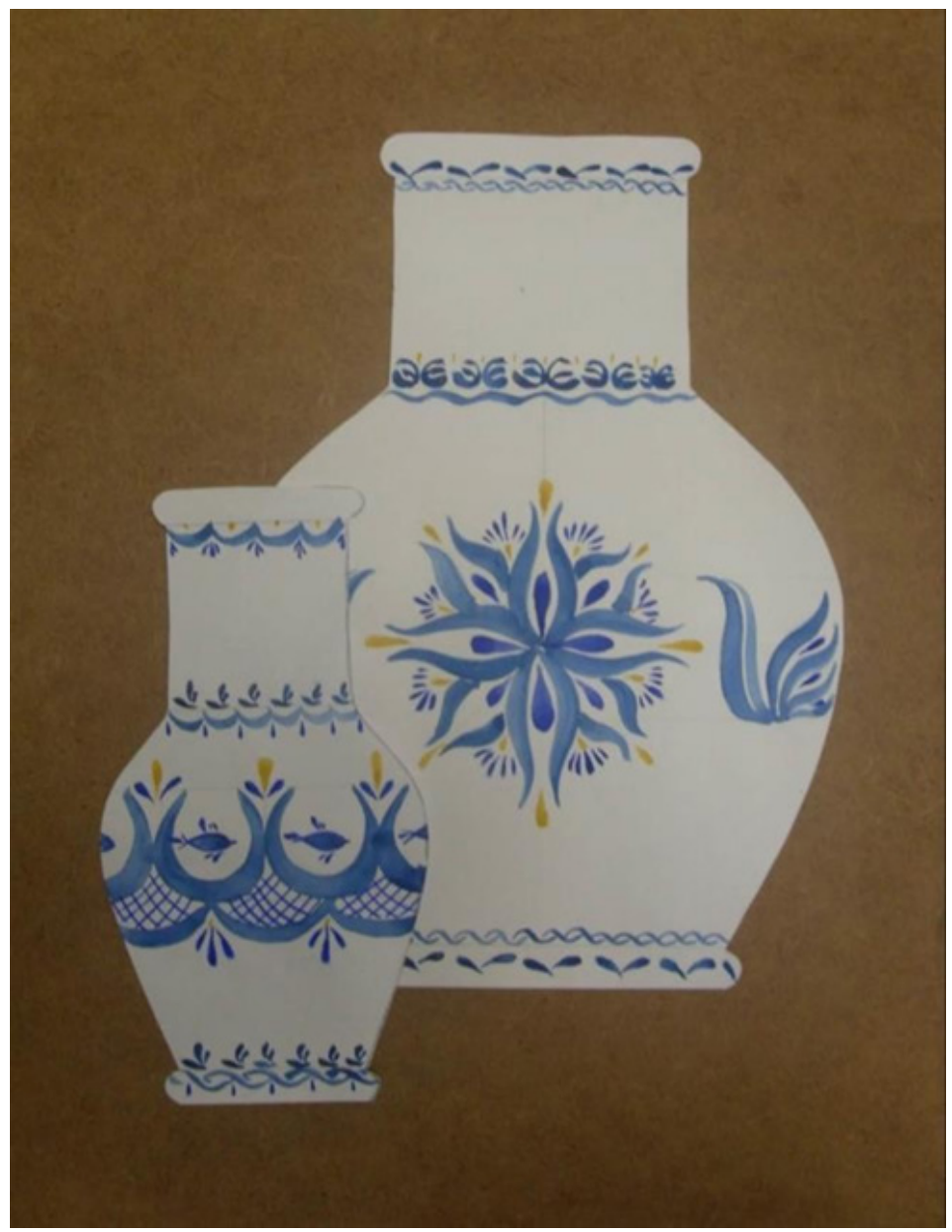

Фото 14 . Шаблони глечиків, розписані елементами таврійського розпису

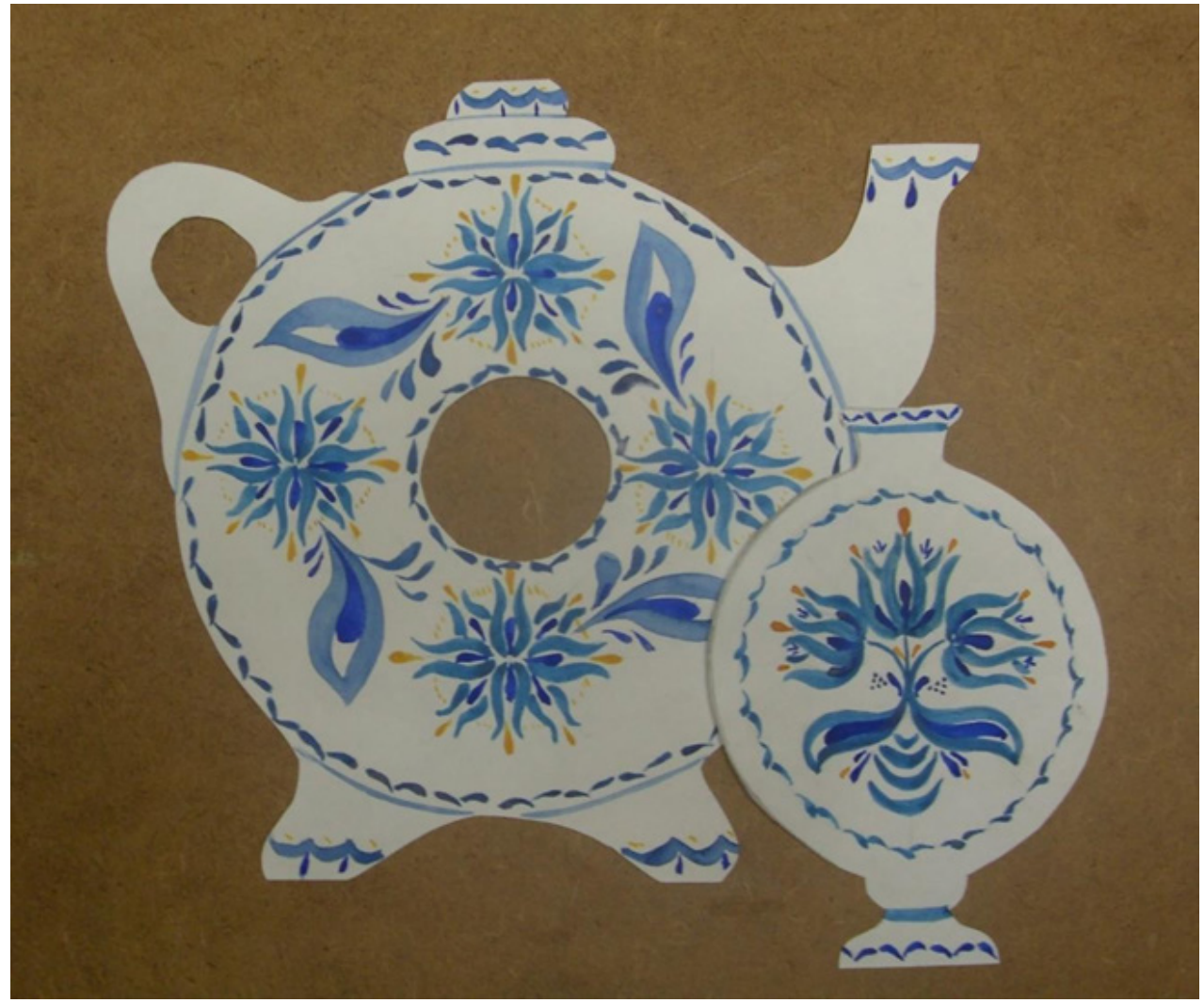

Фото 15. Шаблони куманців, розписані елементами таврійського розпису 


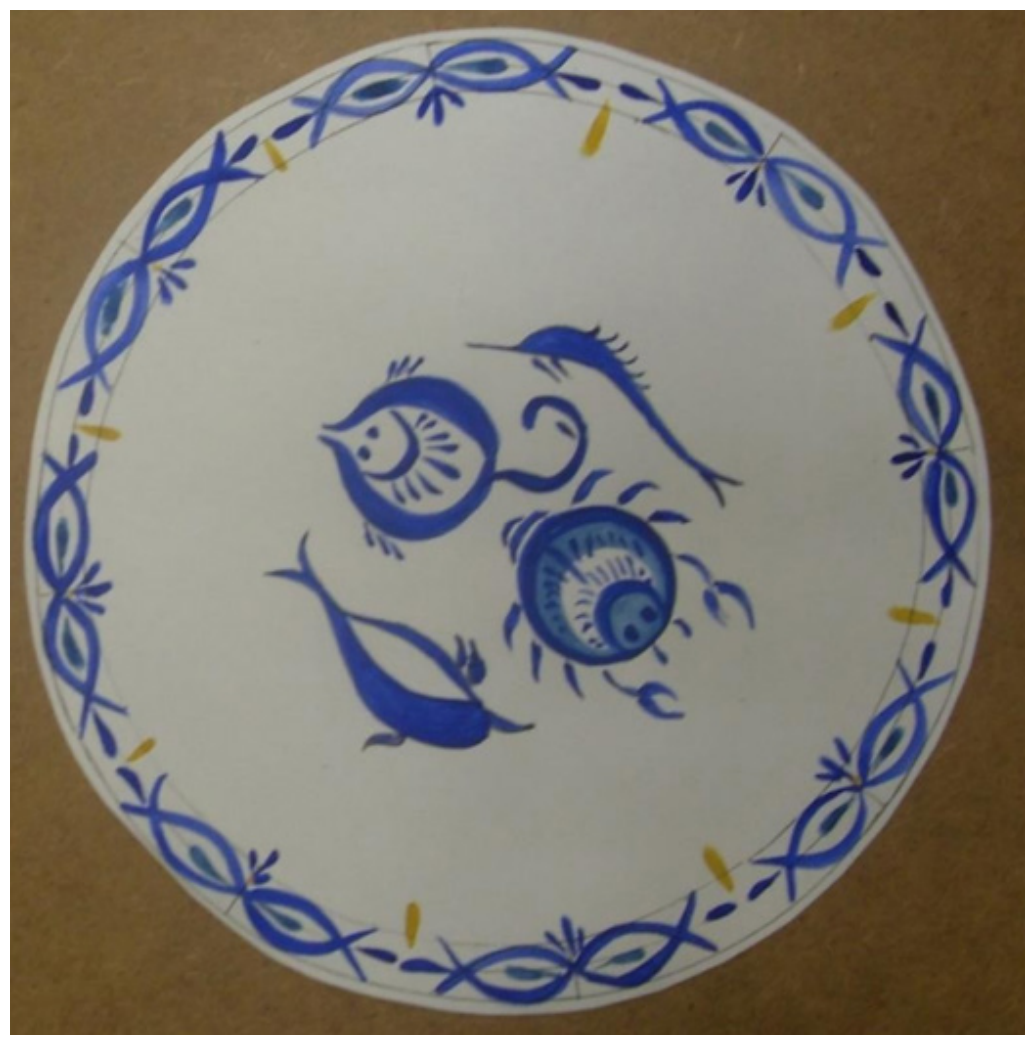

Фото 16. Шаблон тарелі, розписаний зооморфними мотивами таврійського розпису

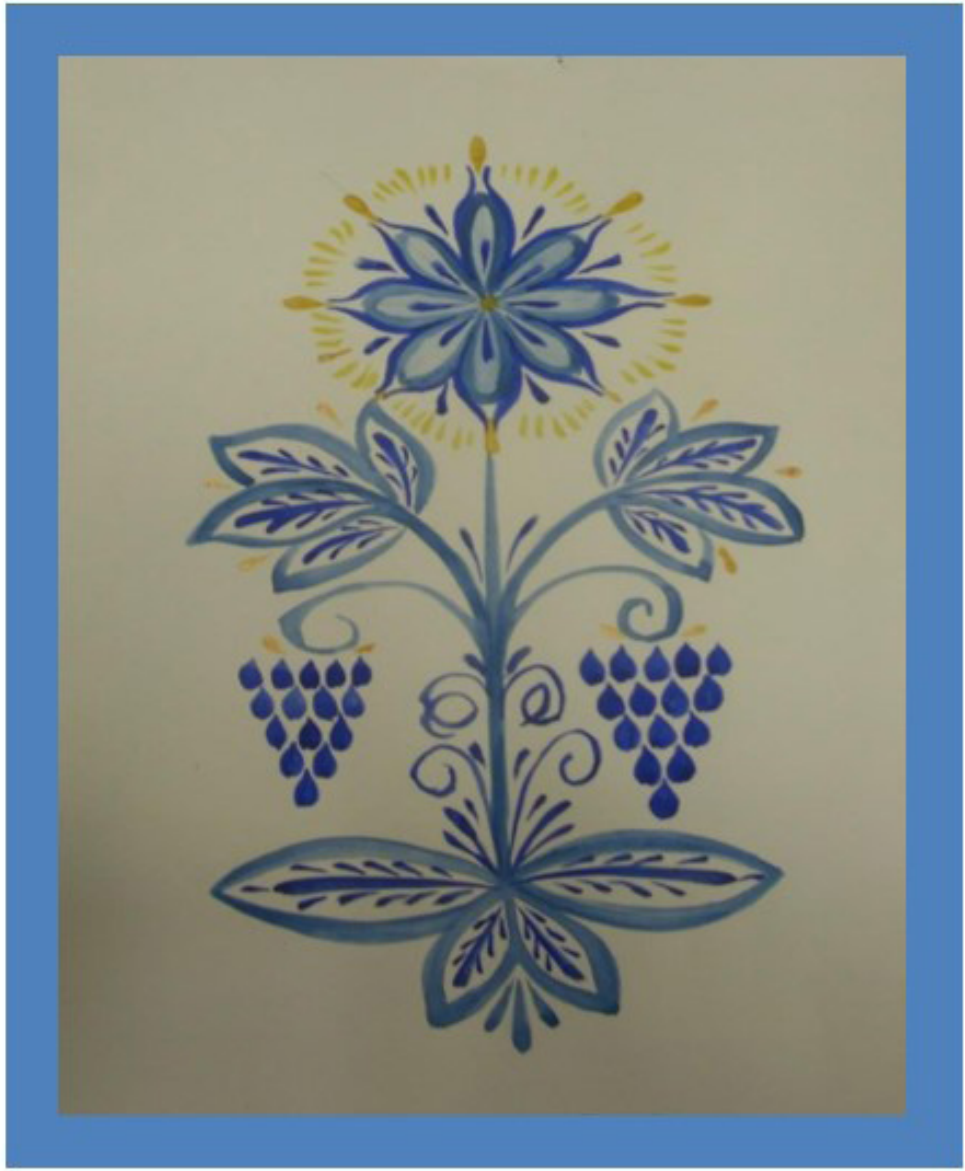

Фото 17. «Дерево життя» 
Отже, у результаті практичної діяльності учні краще засвоюють інформацію, здобувають уміння виконувати таврійський розпис, а також мають можливість для творчого самовираження.

Висновки. Таврійський розпис $\epsilon$ унікальним у декоративно-ужитковому мистецтві України поряд з іншими, відомішими народними розписами - петриківським та самчиківським. Таврійський розпис уперше описано й досліджено в 50-ті роки XX ст. - його відкрила світові й увела під такою назвою у сферу наукових мистецтвознавчих студій журналістка й мисткиня Є. П. Бондаренко. Особливостями таврійського розпису є насамперед морська тематика i образна символіка, прагнення передати в композиціях безмежність морського і небесного простору, використання переважно білого, блакитного, синього кольорів, барви «сивого туману». Основні елементи розпису мають характерні назви: «риба», «матула», «маяк», «медуза», «якірці», «парусник», «морський коник», «краб», «роза вітрів», так само і назви основних мазків: «хвиля», «краплин- ка», «човник», «хмарка», «чайка», «човник із вітрилом».

Уважаємо за необхідне популяризувати цей розпис і ознайомити 3 ним учнів із початкової школи, що, власне, підкріплено нашою педагогічною діяльністю - на уроках мистецтва й у гуртку декоративно-прикладного мистецтва. Уважаємо, що в рамках уроків у 1-4 класах є можливості для того, щоб поступово прилучати учнів до цього розпису, порівнювати його з іншими, вивчати елементи і створювати різні орнаменти, щоб у подальшому переходити до складніших композицій, у яких учні зможуть творчо самовиразитися.

Перспективним уважаємо подальше дослідження таврійського розпису мистецтвознавцями, етнографами і педагогами 3 тим, щоб зберегти культурну спадщину рідного краю, збагатити різноманітний здобуток писанкарства України та в перспективі - розвинути, осучаснити народні традиції, створити нові елементи тощо. Необхідно розробляти програми для гурткової роботи в початковій та інших ланках школи з вивчення таврійського живопису.

\section{ЛІТЕРАТУРА}

1. Бондаренко Є. П. Стежки до Лиману: новели. / за ред. О. В. Топчія / Є. П. Бондаренко. - Миколаїв : ВАРТ, 2010. - Ч. 2. - 64 с.

2. Бондаренко Є. П. Степові скарби. Деякі аспекти народного образотворчого мистецтва Півдня України / Є. П. Бондаренко // Народне мистецтво. - 2004. - № 1-2. C. $48-49$.

3. Паранюк Л., Божкова Г. Таврійський розпис. Унікальний елемент нематеріальної культурної спадщини Миколаївщини / Л. Паранюк, Г. Божкова. - Миколаїв, 2019. - 43 с.

\section{ТАВРИЙСКИЕ УЗОРЫ}

\section{Степанюк Наталья, старший преподаватель} кафедры теории и методики языково-литературного и художественно-эстетического образования Николаевский областной институт последипломного педагогического образования ул. Адмиральская, 4-а, 54001, г. Николаев, Украина natalia.stepaniuk@moippo.mk.ua

Статья посвящена таврийской росписи - уникальному декоративному искусству Николаевского края, истории его возникновения, особенностям символики и орнаменти- 
ки, иветовой гаммы и специфике нанесения элементов. Раскрывается методика освоения таврийской росписи на школьных уроках изобразительного искусства и в условиях кружка, методы и приемы обучения учащихся начальной школь, конкретизированные на приемах выполнения ими отдельных элементов и целостной композиции. Представлено потаговое сопровождение выполнения учениками 1 и 2 классов композиций на основе таврийской росписи, которая изучается в рамках тем программы курса «Искусство» в общеобразовательной школе.

Ключевые слова: кружок декоративно-прикладного искусства; таврийская роспись; уроки изобразительного искусства; ученики начальной школь.

\section{PATTERNS OF TAURIA}

Stepaniuk Natalia, senior lecturer at the Department of Theory and Methods of Language, Literature, Art and Aesthetic Education Mykolaiv In-Service Teachers Training Institute 4-a Admiralska Street, 54001, Mykolaiv, Ukraine natalia.stepaniuk@moippo.mk.ua

The article is devoted to the Tauria painting as a unique art piece of Mykolaiv Region, which represents its history and features (symbols and ornamentation, colours and specific elements). The painting of Tauria was discovered and named by Evhenia Bondarenko in the 1950 s during her traveling along the Black Sea. As a unique system the Tauria painting has got such ornamental decoration which predominates with the patterns of marine, vegetable and animal subjects and reflects the sea life and fishing.

There are main elements of Tauria painting: "a fish», "a lighthouse», "a jellyfish», "anchors», "a sailboat», "a seahorse», "a crab», "a wind rose». Each element differs with its technique. The color scheme of Tauria painting has its own peculiarities (white and light-blue background with plant and animal elements, the composition is special because space is not overloaded with décor details and in such a way it allows us to focus on the plot).

The author presents her own experience of teaching in a primary school. Also she introduces the teaching method according to the Tauria painting at Art classes and in afterclasses activities (using the examples of some paintings).

The step-by-step support of the Tauria painting within the subjects of the program course «Art» for 1-2 grades in a comprehensive school have been proposed. It is really important to study painting of Tauria at school.

Keywords: after-classes activity; Art lessons; painting of Tauria; primary school students.

\section{REFERENCES}

1. Bondarenko, Ye. P. \& Topchiy, O. (Ed.). (2010). Stezhky do Lymanu: novely [Paths to the Estuary: short stories]. Ch. 2. Mykolaiv: VART (ukr).

2. Bondarenko, Ye. P. (2004). Stepovi skarby. Deiaki aspekty narodnoho obrazotvorchoho mystetstva Pivdnia Ukrainy [Steppe treasures. Some aspects of folk art of the Ukrainian South]. Narodne mystetstvo, 1-2, 48-49 (ukr).

3. Paraniuk, L. \& Bozhkova, H.(2019). Tavriiskyi rozpys. Unikalnyi element nematerialnoi kulturnoi spadshchyny Mykolaivshchyny [Taurian painting. A unique element of the intangible cultural heritage of Mykolayiv region]. Mykolaiv (ukr). 